\title{
Variable retention forestry conserves habitat of bird species in Patagonian Nothofagus pumilio forests
}

\author{
María Vanessa Lencinas ${ }^{1 \S}$, Juan Manuel Cellini² ${ }^{2}$ Julieta Benitez ${ }^{1}$, Pablo Luis Peri ${ }^{3}$, \\ Guillermo Martínez Pastur ${ }^{1}$
}

Lencinas M.V., Cellini J.M., Benitez J., Peri P.L., Martínez Pastur G., 2018. Variable retention forestry conserves habitat of bird species in Patagonian Nothofagus pumilio forests. Ann. For. Res. 61(2): 147-160.

Abstract. Variable retention is an alternative harvesting system that could be implemented instead the more traditional ones (e.g. shelterwood cut for N. pumilio forests in southern Patagonia), because it was designed not only for timber purpose, but also for conservation. However, the impact of different retention types on diversity is not clear, e.g. stenotopic and eurytopic bird species. The objective of this work was to analyse the habitats (inside, edge or outside of aggregated retention) and the use of strata (canopy, stem, debris and floor) for different bird species under two different variable retention harvesting types (aggregated + dispersed retentions, or aggregated retention + clear-cuts). We analysed four years of bird observation data in variable retention harvested and unharvested forest permanent plots located in Tierra del Fuego province (Argentina) belonging to PEBANPA (Parcelas de Ecología y Biodiversidad de Ambientes Naturales en Patagonia Austral) network, also with understory and crown cover data. Statistical analysis included uni- and multivariate tests, and comparisons with unharvested forests. We inventoried nine bird species, six of which showed significantly different habitat preference in variable retention types (Carduelis barbata, Phrygilus patagonicus and Tachycineta leucopyga in aggregated + dispersed retentions, and Enicognathus ferrugineus, P. patagonicus, T. leucopyga, Troglodytes aedon and Zonotrichia capensis in aggregated retention + clearcuts). Likewise, all evaluated species presented differential use of strata, and some species changed comparing harvested and unharvested forests. DCA (Detrended Corresponded Analysis) highlighted association between species and habitats (e.g. P. patagonicus is more related to outside aggregated retentions) as well as differences between variable retention types, showing that bird species move toward edges when clear-cuts were carried out, among aggregated retention, instead of dispersed retention. These results support the effectiveness of the variable retention to conserve habitat of bird species inside managed forests, which satisfy both stenotopic and eurytopic species requirements.

Keywords: aggregated retention, biodiversity conservation, dispersed retention, habitats, strata.

Authors. ${ }^{1}$ Centro Austral de Investigaciones Científicas (CONICET), Hous- 
say 200 (9410) Ushuaia - Tierra del Fuego (Argentina) ${ }^{2}$ Facultad de Ciencias Agrarias y Forestales - Universidad Nacional de La Plata, cc 31 (1900) La Plata - Buenos Aires, Argentina ${ }^{3}$ Universidad Nacional de la Patagonia Austral-Instituto Nacional de Tecnología Agropecuaria-CONICET, cc 332 (9400) Río Gallegos - Santa Cruz, Argentina.

§Corresponding author: María Vanessa Lencinas (mvlencinas@conicet.gov.ar) Manuscript received November 4, 2018; revised December 26, 2018; accepted December 29, 2018; online first December 31, 2018.

\section{Introduction}

Biodiversity includes all living organisms that inhabitat an ecosystem, as well as ecosystem diversity, and is crucial for ecosistem services supply, since regulates ecosistem processes and functions, and could be considered ecosystem services in itself (MEA 2005). Ecosystem services are those provided by the flows of materials, energy and information from natural capital stocks, which combined with manufactured and human capital services, produce human welfare sorted in four categories: provisioning, regulating, supporting and cultural services. Currently, forest management is under publicly scrutined concerning its impact in non-timber values (e.g. biodiversity). Therefore, biodiversity conservation becomes one important goal of forestry, including the provision of habitat for forest species. Biodiversity assemblages in natural ecosystems vary across landscape (French \& Picozzi 2002), even within a single vegetation type or region (Gossner et al. 2014, Martínez Pastur et al. 2016, Zolotarjova et al. 2016) following different environmental gradients (e.g., climatic, latitudinal, longitudinal, altitudinal). This was observed in vascular plants and arthropods of Nothofagus pumilio Poepp. \& Endl. Patagonian forests (Lencinas et al. 2017). Birds are not an exemption (Martínez Pastur et al. 2015), being necessary to develop land-sharing strategies to promote conservation in managed ecosystems to safeguard their particularities (in richness, community composition and assemblage patterns) along the whole range of distribution of the species.

Birds are the most abundant and diverse vertebrates in several temperate forests (Vuilleumier 1985). They occupy many ecological niches and key roles, such as seed dispersers, pollinators, pest controllers, soil creators, nutrient cyclers, predators and scavengers (Sekercioglu 2006), providing important ecosystem services (Whelan et al. 2008). For birds, habitat is the place where they are active for feeding, nesting, singing, roosting/perching and covering/sheltering. Some species (eurytopic) are adapted to different habitats (e.g. could eat several types of food, available in different habitats), while other species (stenotopic) require specific habitat (e.g. could eat only one type of food, available in a unique habitat). Forest strata provide different habitat features for bird activities (French \& Picozzi 2002). Therefore, bird distribution and density could be associated with forest strata and structural features, like presence of canopy emergent trees, snags, logs and different understory cover (e.g. Berg et al. 1994, Díaz et al. 2005), most of which could persist in disturbed ecosystems as biological legacies (Perry \& Amaranthus 1997). The lack of suitable strata may threaten the conservation of bird species or communities. The knowledge about bird species habitat requirements improve the effectiveness in the design of conservation strategies (Franklin et al. 1997). Ecosystems with marked temporal and spatial variability in resources usually condition the presence of stenotopic or specialist species, which are usually the more sensitive to changes in habitat features (Devictor et al. 2008). In contrast, more homogeneous ecosystems in space and time are more appropriated for less specialized (and less sensitive) eurytopic or generalist bird 
species (Carrara et al. 2015), less relevant for conservation-oriented management priorities at landscape scale (Becerra Serial \& Grigera 2005, Lencinas et al. 2005, 2009).

Variable retention was proposed as an alternative to achieve both timber and conservation purposes in the management of temperate forests (Franklin et al. 1997). Variable retention differs from other harvesting systems, because it proposes to maintain permanently mature trees, snags and multiple crown and size classes at stand level to preserve both species and structural diversity (Rodewald \& Yahner 2000). Among temperate woodlands, N. pumilio forests of southern Patagonia could be successfully managed with this strategy (Martínez Pastur et al. 2009). The variable retention system in $N$. pumilio forests allows to maintain some of the original biodiversity in managed stands (e.g. Soler et al. 2015), of vascular plants (Lencinas et al. 2011), arthropods (Lencinas et al. 2014) and birds (Lencinas et al. 2009). Specifically, variable retention appears to have a great potential for bird conservation in southern Patagonian forests. In a previous work in these forests, Lencinas et al. (2009) found that variable retention allows the establishment of early-succession birds in harvested areas with dispersed retention and clear-cuts, while conserves in the aggregated retentions birds typical of primary unharvested forests. Contrary, Deferrari et al. (2001) found in $N$. pumilio forests that shelterwood cut reduce diversity at landscape scale decreasing presence and abundance of unharvested forest specialist bird species, which was also stated by King \& DeGraaf (2000) in New Hampshire, USA forest. Similarly, clear-cuts usually only favored early-successional birds and this could lead to a complete replacement of the original bird community (Costello et al. 2000). However, it is not clear which is the impact in the use of habitat and strata caused by different variable retention harvesting types on bird species, both for specialist/sensitive (typical inhabitants of forests) or eurytopic species that usually reach harvested forests from open-lands, as shrublands, grasslands and peat-bogs (Lencinas et al. 2009).

Therefore, the objectives of this work were: (i) to evaluate the effect of different types of variable retention harvesting in the use of different habitats generated in harvested areas (inside aggregates, edges and outside aggregates) by bird species; (ii) to analyse the use of strata (canopy, stem, debris, and floor) within variable retention harvestings types, and to compare them with unharvested forests. We complemented these analyses with other available information (bare soil and debris cover, vegetation biomass, crown cover) as possible explanations for differences in the habitat proportional abundances. The studied types of variable retention were those applied in a long term-plot of the PEBANPA (Parcelas de Ecología y Biodiversidad de Ambientes Naturales en Patagonia Austral) network (Peri et al. 2016), including aggregates in a matrix of dispersed retention, and aggregates within a clear-cut. Through this study, we expected to understand better the role of variable retention harvesting to promote the conservation of native bird species with different habitat requirements.

\section{Materials and methods}

\section{Study sites, forest structure and understory characterization}

We conducted this study in San Justo Ranch $\left(54^{\circ} 06^{\prime} \mathrm{S}, 68^{\circ} 37^{\prime} \mathrm{W}\right)$, where variable retention harvesting on pure (monospecific) unharvested $N$. pumilio forest was applied in 2001 for the first time in Tierra del Fuego, Argentina. Harvested forests are in a long-term permanent surveyed area of 61 ha (Martínez Pastur et al. 2010, Gustafsson et al. 2012), where the full range of site qualities is represented (Martínez Pastur et al. 1997). Therefore, it comprise from high productive stands, with more than $900 \mathrm{~m}^{3}$ 
ha $^{-1}$ of total (timber and non-timber) tree volume and more than $24 \mathrm{~m}$ height, to low productive stands with less than $700 \mathrm{~m}^{3} \mathrm{ha}^{-1}$ total tree volume and less than $20 \mathrm{~m}$ height (Martínez Pastur et al. 2009). Sampling was carried out in two types of variable retention harvesting included in this area: (i) combination of aggregated and dispersed retention $(\mathrm{AR}+\mathrm{DR})$, applied on 10.7 ha, with one aggregate $(30 \mathrm{~m}$ radius) per hectare and $10-15 \mathrm{~m}^{2} \mathrm{ha}^{-1}$ basal area of remaining trees among them (40-50\% of total retention); (ii) aggregated retention surrounded by clear-cut $(\mathrm{AR}+\mathrm{CC})$, applied on $18.5 \mathrm{ha}$, also with one aggregate (30 m radius) per hectare (28\% of total retention). Sampling was also performed in remnant unharvested forests as control (C), occupying 8.6 ha, with 528 trees ha ${ }^{-1}$ density and $65.0 \mathrm{~m}^{2} \mathrm{ha}^{-1}$ basal area. We evaluated these areas as adequate for biodiversity studies using BACI (Before and After Control Impact) approach, as was already published in Lencinas et al. (2005, 2009, 2014, 2017). For the analyses proposed in this study, habitats generated by variable retention were inside aggregates, edges and outside aggregates. In $\mathrm{AR}+\mathrm{DR}$, outside aggregates corresponded to dispersed retention; while in $\mathrm{AR}+\mathrm{CC}$, outside aggregates corresponded to clear-cut.

Forest structure was evaluated in the three forest conditions by random circular plots of $500 \mathrm{~m}^{2}$ each. Complete description of forest structure sampling methodology and general results could be found in Martínez Pastur et al. (2009). Crown cover was extracted from those data for the habitats analysed in this study (inside aggregates, edges and outside aggregates). It was estimated using a spherical crown densiometer (Lemmon 1957) in each plot.

Climate in the study area presents short cool summers and long snowy and frozen winters (Martínez Pastur et al. 2007). The mean monthly temperatures vary from $-0.2^{\circ} \mathrm{C}$ to $10.4^{\circ} \mathrm{C}$ (with $-9.6^{\circ} \mathrm{C}$ minimum extreme in July, and $24.9^{\circ} \mathrm{C}$ maximum in February) in unharvested forests, and from $-1.0^{\circ} \mathrm{C}$ to $10.6^{\circ} \mathrm{C}\left(-11.3^{\circ} \mathrm{C}\right.$ minimum extreme in July to $25.9^{\circ} \mathrm{C}$ maximum 150 in February) in harvested forests. The growing season is short (approximately five months) due to mean monthly temperatures over $0^{\circ} \mathrm{C}$ occurs only three months per year. However, soil temperatures in unharvested stands are never below $0^{\circ} \mathrm{C}$, although soil freezing occurs in harvested stand $\left(-0.2\right.$ to $-0.6^{\circ} \mathrm{C}$ during June-July). Rainfall that reach the forest floor, including snowfall, is around $600 \mathrm{~mm} \mathrm{yr}^{-1}$ in the harvested stands, but lesser (300-400 mm $\mathrm{yr}^{-1}$ ) inside unharvested forests due to canopy interception. Winds have an annual average speed of $8 \mathrm{~km} \mathrm{~h}^{-1}$ outside forests, reaching up to $100 \mathrm{~km} \mathrm{~h}^{-1}$ during storms.

Vascular plant diversity in $N$. pumilio forest understory is usually scarce, with low development in height (less than $1.00 \mathrm{~m}$ ) and without shrubs or sub-canopy components (Lencinas et al. 2008a), but with a rich bryophyte component (Lencinas et al. 2008b). We characterized vegetation of harvested and unharvested forests by ten randomly located plots $\left(1 \mathrm{~m}^{2}\right.$ each) in each, following the methodology described in Lencinas et al. (2011). We evaluated cover and biomass for the studied habitats (inside aggregates, edges and outside aggregates). The covers $(\%)$ of woody debris and bare soil or litter without vegetation were estimated by interception method in each plot (Mueller-Dombois \& Ellenberg 1974). The monocot, dicot and total dry biomass $\left(\mathrm{kg} \mathrm{ha}^{-1}\right)$ were obtained by drying in oven at $70^{\circ} \mathrm{C}$ (Catchpole \& Wheeler 1992). Total dry biomass included monocot, dicot and bryophyte biomass.

\section{Bird sampling}

Bird sampling was performed by point-count sampling method with unlimited distances (Deferrari et al. 2001, Lencinas et al. 2005, 2009) during the summer season (February) of the first four years after harvesting (2002$2005)$ in the three described forest conditions. Sampling was conducted when major social and feeding bird activity occurs (4-h period following sunrise), and under equivalent climatic conditions, discarding foggy, strong 
windy or rainy days. We randomly established six sampling points in each forest condition (at least $100 \mathrm{~m}$ apart one from other), clearly identified in the field, which were visited five times during each summer, reaching 360 total counts. Sampling point order was changed daily to balance the effect of day-time on bird observations (Shields 1977). Each count consisted in 10-minute observation period, including 2-minute period of habituation (time taken by birds to return to their normal activities) and 8-minute period of effective counting (direct sighting recognition of each individual with binoculars). During observation, we registered taxonomy, habitat (inside aggregates, edges or outside aggregates) and strata or tier of the forests where each individual is observed (canopy, stem, debris and floor), as was suggested by O'Donnell \& Dilks (1988). Moreover, we measured the horizontal distance (m) between each bird or groups and the center of the point, using a TruPulse laser rangefinder (Laser Technology, USA), to calculate density. Lencinas et al. (2009) published the analyses for richness and density.

Strata in our study area were defined based on an adaptation of the strata levels proposed by Pearson (1971). Canopy stratum occupied the upper $1 / 4$ of the total height of the overstory tree (approximately 16 m-24 m height), and include disperse and uncommon emergent trees. Stem stratum occupied from the floor level to $3 / 4$ total height, and comprised the trunk or main branches of the overstory tree. Debris stratum occupied from the floor level to approximately $1.50 \mathrm{~m}$ height, and included the crown and branches of harvested trees (only logs are productively used). Floor stratum was less than $0.50 \mathrm{~m}$ height, and included bare soil or litter without vegetation, and understory. Bird taxonomy followed Narosky \& Yzurieta (1987) as presented in the Supporting Information.

\section{Data analyses}

The abundance of each bird species per hab- itat and strata was relativized to the total abundance of the species in variable retention harvested forests, obtaining a proportional abundance (\%) for each sampled year (replicas). We only evaluated species observed in more than one sampling year. The proportional abundance was analysed by univariate and multivariate statistic. For the characterization of bird species behaviour in harvested forests, we performed two-way ANOVAs, considering habitats (inside aggregates, edges and outside aggregates) and strata (canopy, stem, debris and floor) as main factors $(N=48)$, in both $\mathrm{AR}+\mathrm{DR}$ and $\mathrm{AR}+\mathrm{CC}$ variable retention harvestings. Likewise, we performed one-way ANOVAs for understory biomass and cover, as well as for crown cover, considering habitats (inside aggregates, edges and outside aggregates) as main factor. Biomass was log transformed by $\log (\mathrm{Y}+1)$ to achieve normality (Kolmogorov-Smirnov test) and homoscedasticity (Levene test) assumptions, but non-transformed data are shown. Averages were tested for significant differences by Tukey test $(p<$ $0.05)$ in all these analyses. Moreover, we performed non-parametric analyses of variance by Kruskal-Wallis test to compare among strata for each bird species in unharvested forests. We used Statgraphics (Statistical Graphics Corp., USA) software for all the analyses.

Complementary, we conducted a detrended correspondence analysis (DCA - Hill 1979) to evaluate the change in direction and magnitude of bird species behaviour between $\mathrm{AR}+\mathrm{DR}$ and $\mathrm{AR}+\mathrm{CC}$ variable retention harvestings. This ordination utilized species average proportional abundance data and was developed with rescaling of axes and without down-weighting for rare species in PC-Ord software (McCune \& Mefford 1999).

\section{Results}

We analysed nine bird species for variable retention harvestings, most belonging to Passeriforms (four resident and/or partial migratory 
and four migratory) and only one Psittaciform (resident) (Supp. Info.).

In AR+DR (table 1), three species (Carduelis barbata, Phrygilus patagonicus and Tachycineta leucopyga) presented significantly different proportional abundance in the habitats $(\mathrm{F}>4.34, \mathrm{p}<0.020)$, with significantly higher abundance (61\% to $94 \%)$ in dispersed retention among aggregates than inside aggregates $(0 \%$ to $11 \%)$. Edges showed intermediate values $(6 \%$ to $28 \%)$, which cannot be differentiated of inside aggregates for P. patagonicus, and inside and outside aggregates for $C$. barbata and T. leucopyga. Regarding strata, almost all species preferred one or two strata instead of other strata $(\mathrm{F}>3.78, \mathrm{p}<0.019)$, except Zonotrichia capensis $(\mathrm{F}=1.42, \mathrm{p}=$ $0.254)$ that did not show any preference. The species that preferred canopy instead of other strata were C. barbata, Elaenia albiceps, Enicognathus ferrugineus and T. leucopyga, with $50 \%$ to $96 \%$ preference. Two species preferred floor (P. patagonicus and Troglodytes aedon, with $65 \%$ to $82 \%$ preference), and other two species occupied canopy and floor with similar frequency (Aphrastura spinicauda, with $32 \%$ in floor and $36 \%$ in canopy, and Turdus falklandii, with $26 \%$ in canopy and $57 \%$ in floor). However, significant interactions were detected for P. patagonicus and T. leucopyga ( $\mathrm{F}>4.13, \mathrm{p}<0.003)$, where the first species showed very low proportional abundance (less than 5\%) in all strata, in edges and inside aggregates, while in dispersed retention reached a maximum in floor $(65 \%)$, intermediate values in canopy (20\%), and low values in debris and stems. On the other hand, the significant interaction for $T$. leucopyga occurred by selecting mainly canopy in dispersed retention $(60 \%)$, compared with edges and aggregates (approximately $20 \%$ vs. less than $2 \%$, respectively).

In $\mathrm{AR}+\mathrm{CC}$ (table 2), five species (E. $f e$ rrugineus, $P$. patagonicus, $T$. leucopyga, $T$. aedon and $Z$. capensis) presented significantly different proportional abundance between habitats $(\mathrm{F}>3.28, \mathrm{p}<0.049)$ : four of them with significantly higher abundance $(66 \%$ to $80 \%$ ) in clear-cut among aggregates than inside aggregates (1\% to $4 \%$ ), while $E$. ferrugineus was more significantly frequently observed in edges $(56 \%)$. On the other hand,

Table 1 Proportional abundance (\%) of bird species in harvested Nothofagus pumilio forests, where variable retention type includes aggregated and dispersed retention. Habitats and strata were the main factors to evaluate preferences by two-way ANOVAs. Codes for the species are in Supp. Info.

\begin{tabular}{|c|c|c|c|c|c|c|c|c|c|c|}
\hline$\overline{\text { Factor }}$ & & APSP & $\mathrm{CABA}$ & ELAL & ENFE & PHPA & TALE & TRAE & TUFA & ZOCA \\
\hline \multirow{5}{*}{$\begin{array}{l}\text { A: } \\
\text { Habi- } \\
\text { tats }\end{array}$} & Inside aggregates & 39.2 & $8.3^{\mathrm{a}}$ & 36.4 & 46.0 & $0.0^{\mathrm{a}}$ & $10.9^{\mathrm{a}}$ & 14.8 & 26.2 & 7.4 \\
\hline & Edges & 25.0 & $19.6^{\mathrm{ab}}$ & 45.4 & 30.2 & $5.9^{\mathrm{a}}$ & $28.2^{\mathrm{ab}}$ & 27.2 & 29.5 & 13.4 \\
\hline & Dispersed retention & 35.8 & $72.1^{\mathrm{b}}$ & 18.2 & 23.8 & $94.1^{\mathrm{b}}$ & $60.9^{b}$ & 58.0 & 44.3 & 79.2 \\
\hline & $\bar{F}$ & 1.01 & 5.35 & 0.74 & 0.14 & 25.54 & 4.34 & 1.29 & 0.40 & 2.44 \\
\hline & $(p)$ & $(0.373)$ & $(0.009)$ & $(0.487)$ & $(0.872)$ & $(<0.001)$ & $(0.020)$ & $(0.287)$ & $(0.670)$ & $(0.102)$ \\
\hline \multirow{6}{*}{$\begin{array}{l}\text { B: } \\
\text { Strata }\end{array}$} & Canopy & $35.8^{\mathrm{b}}$ & $49.3^{b}$ & $95.5^{\mathrm{b}}$ & $93.6^{\mathrm{b}}$ & $23.5^{\mathrm{a}}$ & $94.5^{\mathrm{b}}$ & $3.7^{\mathrm{a}}$ & $26.2^{\mathrm{ab}}$ & 22.8 \\
\hline & Stem & $19.9^{\mathrm{ab}}$ & $1.7^{\mathrm{a}}$ & $4.5^{\mathrm{a}}$ & $3.2^{\mathrm{a}}$ & $0.0^{\mathrm{a}}$ & $3.9^{\mathrm{a}}$ & $0.0^{\mathrm{a}}$ & $3.3^{\mathrm{a}}$ & 2.0 \\
\hline & Debris & $11.9^{\mathrm{a}}$ & $1.5^{\mathrm{a}}$ & $0.0^{\mathrm{a}}$ & $0.0^{\mathrm{a}}$ & $11.8^{\mathrm{a}}$ & $0.0^{\mathrm{a}}$ & $14.8^{\mathrm{a}}$ & $13.1^{\mathrm{a}}$ & 52.4 \\
\hline & Floor & $32.4^{\mathrm{ab}}$ & $4.7^{\mathrm{a}}$ & $0.0^{\mathrm{a}}$ & $3.2^{\mathrm{a}}$ & $64.7^{b}$ & $1.6^{\mathrm{a}}$ & $81.5^{b}$ & $57.4^{b}$ & 22.8 \\
\hline & $\bar{F}$ & 3.78 & 11.81 & 6.44 & 6.75 & 11.25 & 21.44 & 13.8 & 4.63 & 1.42 \\
\hline & (p) & (0.019) & $(<0.001)$ & $(0.002)$ & $(0.001)$ & $(<0.001)$ & $(<0.001)$ & $(<0.001)$ & $(0.008)$ & $(0.254)$ \\
\hline \multirow{2}{*}{$A \times B$} & $F$ & 2.15 & 1.89 & 0.74 & 0.67 & 9.75 & 4.13 & 0.87 & 1.90 & 0.36 \\
\hline & $(p)$ & (0.071) & (0.109) & $(0.626)$ & $(0.673)$ & $(<0.001)$ & $(0.003)$ & $(0.526)$ & (0.107) & $(0.897)$ \\
\hline
\end{tabular}

Note. F(p) - Fisher statistic with probability between parentheses. Different letters in each column show differences by Tukey test at $p<0.05$. 
Table 2 Proportional abundance (\%) of bird species in harvested Nothofagus pumilio forests, where variable retention type includes aggregates surrounded by clear-cut. Habitats and strata were the main factors to evaluate preferences by two-way ANOVAs. Codes for the species are in the Supp. Info.

\begin{tabular}{|c|c|c|c|c|c|c|c|c|c|c|}
\hline Factor & & APSP & CABA & ELAL & ENFE & PHPA & TALE & TRAE & TUFA & $\overline{\mathrm{ZOCA}}$ \\
\hline \multirow{5}{*}{$\begin{array}{l}\text { A: } \\
\text { Habitats }\end{array}$} & Inside aggregates & 8.3 & 4.2 & 30.5 & $20.8^{\mathrm{a}}$ & $1.1^{\mathrm{a}}$ & $3.6^{\mathrm{a}}$ & $3.6^{\mathrm{a}}$ & 16.9 & $1.5^{\mathrm{a}}$ \\
\hline & Edges & 39.1 & 24.6 & 56.5 & $55.8^{\mathrm{b}}$ & $19.1^{\mathrm{a}}$ & $43.7^{\mathrm{ab}}$ & $26.4^{\mathrm{ab}}$ & 47.7 & $32.4^{\mathrm{ab}}$ \\
\hline & Clear-cut & 52.6 & 71.2 & 13.0 & $23.4^{\mathrm{a}}$ & $79.8^{\mathrm{b}}$ & $52.7^{\mathrm{b}}$ & $70.0^{\mathrm{b}}$ & 35.4 & $66.1^{\mathrm{b}}$ \\
\hline & $\bar{F}$ & 1.85 & 1.83 & 1.52 & 3.52 & 7.30 & 5.45 & 3.28 & 1.46 & 3.38 \\
\hline & $(p)$ & $(0.172)$ & $(0.175)$ & $(0.233)$ & $(0.040)$ & $(0.002)$ & $(0.008)$ & $(0.049)$ & $(0.245)$ & $(0.045)$ \\
\hline \multirow{6}{*}{$\begin{array}{l}\text { B: } \\
\text { Strata }\end{array}$} & Canopy & 17.9 & 45.6 & $87.0^{\mathrm{b}}$ & $76.6^{\mathrm{b}}$ & $4.5^{\mathrm{a}}$ & $92.8^{\mathrm{b}}$ & $2.7^{\mathrm{a}}$ & $18.5^{\mathrm{a}}$ & $9.3^{\mathrm{a}}$ \\
\hline & Stem & 11.5 & 0.5 & $0.0^{\mathrm{a}}$ & $0.0^{\mathrm{a}}$ & $0.0^{\mathrm{a}}$ & $0.6^{\mathrm{a}}$ & $0.0^{\mathrm{a}}$ & $1.5^{\mathrm{a}}$ & $1.2^{\mathrm{a}}$ \\
\hline & Debris & 38.5 & 16.2 & $0.0^{\mathrm{a}}$ & $0.0^{\mathrm{a}}$ & $46.1^{\mathrm{ab}}$ & $1.8^{\mathrm{a}}$ & $37.3^{\mathrm{ab}}$ & $9.2^{\mathrm{a}}$ & $39.8^{\mathrm{ab}}$ \\
\hline & Floor & 32.1 & 37.7 & $13.0^{\mathrm{a}}$ & $23.4^{\mathrm{ab}}$ & $49.4^{\mathrm{b}}$ & $4.8^{\mathrm{a}}$ & $60.0^{\mathrm{b}}$ & $70.8^{\mathrm{b}}$ & $49.7^{\mathrm{b}}$ \\
\hline & $\bar{F}$ & 1.51 & 2.50 & 8.65 & 9.00 & 4.67 & 21.12 & 6.12 & 6.18 & 5.47 \\
\hline & (p) & $(0.228)$ & $(0.075)$ & $(<0.001)$ & $(0.001)$ & $(0.007)$ & $(<0.001)$ & $(0.002)$ & $(0.002)$ & $(0.003)$ \\
\hline \multirow{2}{*}{$\mathrm{A} \times \mathrm{B}$} & $F$ & 1.60 & 1.27 & 3.00 & 4.41 & 4.04 & 3.36 & 1.60 & 0.76 & 1.57 \\
\hline & (p) & $(0.176)$ & $(0.294)$ & $(0.017)$ & $(0.002)$ & $(0.003)$ & $(0.009)$ & $(0.176)$ & $(0.609)$ & $(0.184)$ \\
\hline
\end{tabular}

seven species showed strong preferences for some strata $(\mathrm{F}>4.67, \mathrm{p}<0.007) ;$ A spinicau$d a$ and $C$. barbata being the exceptions $(\mathrm{F}<$ $2.50, \mathrm{p}>0.075)$. Among the preferred strata, three species were more associated with canopy (E. albiceps, E. ferrugineus and T. leucopyga, with $77 \%$ to $93 \%$ preference). The other four (P. patagonicus, T. aedon, T. falklandii and $Z$. capensis) were more associated to the floor $(49 \%$ to $70 \%)$, with intermediate values for three of them (P. patagonicus, T. aedon and Z. capensis) in debris (37\% to $46 \%$, without statistical significance between floor and canopy). In these analyses, we observed significant interactions. For E. albiceps and E. ferrugineus, these occurred due to lower values for all strata in dispersed retention (less than 10\%), but significantly higher in the other habitats in canopy, with edges similar to aggregates for E. albiceps (30\% and 50\%, respectively), and aggregates lower than edges for E. ferrugineus (20\% and 60\%, respectively). For T. leucopyga, proportional abundance was greater in canopy than other strata in all the habitats, but with significant differences among them (edge $>$ dispersed retention $>$ aggregates), varying among $10 \%$ and $55 \%$ approximately. The interactions for $P$. patagonicus occurred due to very low proportional abundance in all strata for aggregates and edges, but significantly high proportional abundance in floor in dispersed retention.

DCA (fig. 1) showed changes in direction and magnitude of bird species preference between habitats of $\mathrm{AR}+\mathrm{DR}$ and $\mathrm{AR}+\mathrm{CC}$ variable retention harvestings. Six species $(E$. albiceps, E. ferrugineus, P. patagonicus, $T$. leucopyga, T. falklandii and Z. capensis) enlarged the use of edges when clear-cut was applied, two species increased the use of outside aggregates (A. spinicauda and T. aedon), and $C$. barbata almost did not change from $\mathrm{AR}+\mathrm{DR}$ to $\mathrm{AR}+\mathrm{CC}$.

Use of strata in unharvested forests (fig. 2) was analysed in nine bird species (seven Passeriforms, one Psittaciform and one Falconiform) of the 14 observed bird species. Eight species showed significant preferences of strata $(\mathrm{K}-\mathrm{W}>9.77, \mathrm{p}<0.0206)$ : most of them $(A$. spinicauda, C. barbata, E. albiceps, E. ferrugineus, $P$. patagonicus and Z. capensis) strongly preferred canopy (more than $66 \%$ of the observations); T. aedon was the only one that preferred floor $(67 \%)$; and T. falklandii was the only with similar and high use of canopy and floor (48\% and $50 \%$, respectively) than 
other strata. The Falconiform species (Milvago chimango) was exclusively observed in the canopy stratum.

Finally, complementary analysis on vegetation of AR+DR (table 3) showed significant differences among habitats for bare soil cover, dicot and total biomass, and crown cover $(\mathrm{F}>$
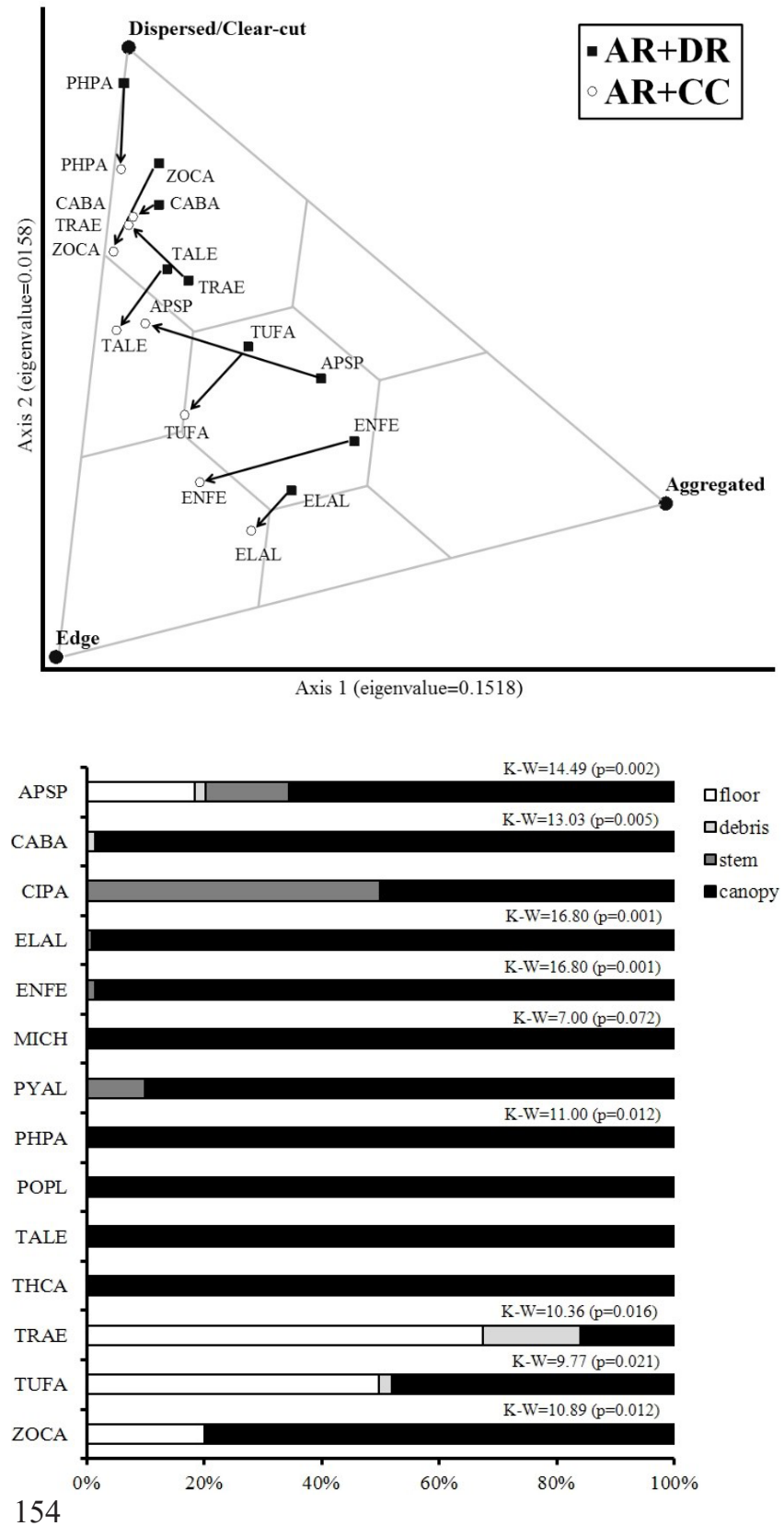

$5.18, \mathrm{p}<0.032)$. Bare soil and crown covers were significantly greater in aggregates (41\% and $82 \%$, respectively) than in dispersed retention (18\% and $24 \%$, respectively), with intermediate values for edges (58\%). Meanwhile, dicots and total biomass were significantly higher in edges and dispersed retention (837.2 $\mathrm{kg} \mathrm{ha}^{-1}$ in average for dicots, and $1368.8 \mathrm{~kg} \mathrm{ha}^{-1}$ for total biomass) than in aggregates (107.0 and $428.1 \mathrm{~kg} \mathrm{ha}^{-1}$, respectively). On the other hand, analysis on vegetation of $\mathrm{AR}+\mathrm{CC}$ (table 3 ) showed a similar pattern than in $\mathrm{AR}+\mathrm{DR}$. We observed significant differences among habitats for bare soil cover, dicot and total biomass, and crown cover $(\mathrm{F}>9.90, \mathrm{p}<0.005)$, with greater differences for bare

\section{Figure 1}

Detrended Correspondence Analysis (DCA) for the proportional abundance (\%) of bird species in the three habitats (inside aggregates, edges and outside aggregates), in Nothofagus pumilio variable retention harvested forests where aggregated and dispersed retention were combined (AR+DR) and where aggregates were surrounded by clear-cut $(A R+C C)$. Arrows pointed the changes of the bird species behaviour between harvesting treatments. Codes for the species are in the Supp. Info.

\section{Figure 2}

Differences in strata use by bird species of Nothofagus pumilio unharvested forests, based on their proportional abundance (\%). Codes for the species are in the Appendix. K-W - Kruskal-Wallis non-parametric analysis of variance; $p$ - probability of the statistical test. Species without test information have not enough replicas for calculations. 
Table 2 One-way ANOVA results for understory cover (bare soil or litter without vegetation and woody debris), biomass (monocots, dicots and total), and crown cover in Nothofagus pumilio variable retention harvested forests, where aggregated and dispersed retention were combined (AR+DR) and where aggregates were surrounded by clear-cut $(\mathrm{AR}+\mathrm{CC})$, considering environments (inside aggregates, edges and outside aggregates) as the main factor.

\begin{tabular}{|c|c|c|c|c|c|c|c|}
\hline $\begin{array}{l}\text { Variable } \\
\text { retention }\end{array}$ & Factor & $\begin{array}{l}\text { Woody debris } \\
(\%)\end{array}$ & $\begin{array}{l}\text { Bare soil } \\
(\%)\end{array}$ & $\begin{array}{l}\text { Monocots* } \\
\left(\mathrm{kg} \mathrm{ha}^{-1}\right)\end{array}$ & $\begin{array}{l}\text { Dicots* } \\
\left(\mathrm{kg} \mathrm{ha}^{-1}\right)\end{array}$ & $\begin{array}{l}\text { Total biomass* } \\
\left(\mathrm{kg} \mathrm{ha}^{-1}\right)\end{array}$ & $\begin{array}{l}\text { Crown cover } \\
(\%)\end{array}$ \\
\hline \multirow{4}{*}{$\mathrm{AR}+\mathrm{DR}$} & Aggregates & 34.3 & $41.2^{\mathrm{b}}$ & 39.8 & $107.0^{\mathrm{a}}$ & $428.1^{\mathrm{a}}$ & $82.3^{c}$ \\
\hline & Edges & 27.5 & $25.8^{\mathrm{ab}}$ & 33.8 & $889.9^{\mathrm{b}}$ & $1680.3^{\mathrm{b}}$ & $58.1^{\mathrm{b}}$ \\
\hline & $\begin{array}{l}\text { Dispersed } \\
\text { retention }\end{array}$ & 33.4 & $18.1^{\mathrm{a}}$ & 129.2 & $784.6^{\mathrm{b}}$ & $1057.3^{\mathrm{b}}$ & $24.0^{\mathrm{a}}$ \\
\hline & $\begin{array}{l}F \\
(p)\end{array}$ & $\begin{array}{l}0.84 \\
(0.462)\end{array}$ & $\begin{array}{l}5.18 \\
(0.032)\end{array}$ & $\begin{array}{l}1.27 \\
(0.331)\end{array}$ & $\begin{array}{l}15.71 \\
(0.001)\end{array}$ & $\begin{array}{l}10.83 \\
(0.004)\end{array}$ & $\begin{array}{l}107.12 \\
(<0.001)\end{array}$ \\
\hline \multirow{4}{*}{$\mathrm{AR}+\mathrm{CC}$} & Aggregates & 25.3 & $48.3^{\mathrm{b}}$ & 48.1 & $102.6^{\mathrm{a}}$ & $518.0^{\mathrm{a}}$ & $87.8^{c}$ \\
\hline & Edges & 34.5 & $18.1^{\mathrm{a}}$ & 150.1 & $860.7^{\mathrm{b}}$ & $1442.3^{\mathrm{b}}$ & $30.3^{\mathrm{b}}$ \\
\hline & Clear-cuts & 41.4 & $17.3^{\mathrm{a}}$ & 315.6 & $918.5^{\mathrm{b}}$ & $1486.1^{\mathrm{b}}$ & $4.0^{\mathrm{a}}$ \\
\hline & $\begin{array}{l}F \\
(p)\end{array}$ & $\begin{array}{l}2.04 \\
(0.186)\end{array}$ & $\begin{array}{l}13.29 \\
(0.002)\end{array}$ & $\begin{array}{l}1.38 \\
(0.306)\end{array}$ & $\begin{array}{l}9.90 \\
(0.005)\end{array}$ & $\begin{array}{l}12.57 \\
(0.002)\end{array}$ & $\begin{array}{l}432.19 \\
(<0.001)\end{array}$ \\
\hline
\end{tabular}

Note. Abbreviations: * - variables $\log (\mathrm{Y}+1)$ transformed prior to the analyses to accomplish ANOVA assumptions. Not transformed means are presented in the table. $\mathrm{F}(\mathrm{p})$ - Fisher statistic with probability between parentheses. Different letters in each column show differences by Tukey test at $\mathrm{p}<0.05$.

soil cover between clear-cuts or edges (17\% to $18 \%$ cover, respectively) vs. aggregates (48\%). Meanwhile, the crown cover gradient in $\mathrm{AR}+\mathrm{CC}$ was similar to the observed in $\mathrm{AR}+\mathrm{DR}(\mathrm{CC}<$ edges $<\mathrm{AR})$, but with lower values in edges $(30 \%)$ and outside aggregates (4\%). Dicots and total biomass repeated the trend (edges $=\mathrm{CC}<\mathrm{AR}$ ), with $889.6 \mathrm{~kg} \mathrm{ha}^{-1}$ in average between edges and clear-cuts for dicots, and $1464.2 \mathrm{~kg} \mathrm{ha}^{-1}$ for total biomass) than in aggregates (102.6 and $518.0 \mathrm{~kg} \mathrm{ha}^{-1}$, respectively).

\section{Discussion}

The nine native bird species analysed in this work were those better in harvested N. pumilio forests (Deferrari et al. 2001, Lencinas et al. 2009). Resident birds dominated the assemblage in unharvested forests, as other authors found in the region (Pizarro et al. 2012, Martínez Pastur et al. 2015). However, migrant and resident/partial migratory birds composed equally the complete assemblage. It may indicates more favourable conditions for migrant birds in harvested forests, concerning to competition for resources such as food, refuge, and nesting sites, demonstrating the importance of harvested areas for migrant birds. The species observed in harvested forests were also abundant in other $N$. pumilio forests of Tierra del Fuego (Schlatter 1995, Venegas 2000, Deferrari et al. 2001), and are widely distributed in Argentina and Chile (Humphrey et al. 1970, Clark 1986).

Structural heterogeneity in the landscape is an important determinant of bird diversity, where both homogeneous and heterogeneous landscape types have special value for different functional groups (French \& Picozzi 2002). The habitat features were more homogeneous in $\mathrm{AR}+\mathrm{DR}$, since less species presented significantly different use of habitats than in $\mathrm{AR}+\mathrm{CC}$. This last retention type was more heterogeneous in forest and understory vegetation structure (table 3). Monocot biomass causes the main differences, because it was 
more than two fold greater in $\mathrm{AR}+\mathrm{CC}$ than in $\mathrm{AR}+\mathrm{DR}$ (table 3 ). In this context, the eurytopic species $P$. patagonicus and $T$. leucopyga showed similar preferences patterns in both variable retention types (outside $>$ edges $>$ inside aggregates). This result differed from the expected according to the habitat-use guild classification proposed by Díaz et al. (2005) for Chilean temperate rainforests. P. patagonicus is a vertical-profile generalist for these authors, associated with profuse branching and canopy foliage, but we mainly observed this species outside aggregates probably due to less food offer along the vertical profile in our forests. On the other hand, T. leucopyga is categorized as large-tree user (Díaz et al. 2005), probably by their dependence on cavities to nesting (Altamirano et al. 2012), which are more common in large trees. However, we observed this species more frequently flying, feeding or roosting in open spaces among aggregates instead in the aggregates where they should have their nests, showing that both habitats may be important for this species. Moreover, we rarely observed T. leucopyga in unharvested forests, probably because closed and shaded forests limit their flight and insect catch.

Openings attracted three eurytopic species (C. barbata, T. aedon and Z. capensis) in both retention types, while stenotopic E. ferrugineus moved more to the edges in $\mathrm{AR}+\mathrm{CC}$, but remain inside aggregates in $\mathrm{AR}+\mathrm{DR}$. According to Díaz et al. (2005), C. barbata and T. aedon are shrub-users that are common in shrub patches and piles of woody debris (this last more abundant outside aggregates). The same is likely similar for Z. capensis. Meanwhile, E. ferrugineus is a cavity nester (Altamirano et al. 2012) associated with large trees that has low predation risk due to their relatively big size. Therefore, it has no need to be hidden and protected inside closed forests. DCA analysis highlighted differences in the use of habitats generated by retentions.

Concerning to the use of strata, many stenotopic and eurytopic species maintain this similar in harvested and unharvested forests (C. barbata, E. albiceps, E. ferrugineus and $T$. leucopyga in canopy, and T. aedon in floor). Several authors stated that species grouping in canopy is mainly based on their foraging pattern (e.g. French \& Picozzi 2002), more than in the space needed to fly (Partasasmita et al. 2017). In this sense, both $C$. barbata and $E$. albiceps feed indistinctly from grains, fruits, buds and insects (Humphrey et al. 1970, Smith Ramírez \& Armesto 1998, Brown et al. 2007), which are all abundant in the crown of $N . p u$ milio trees (Lencinas et al. 2008c, 2014; Martínez Pastur et al. 2008). Similarly, E. ferrugineus feeds mainly pollen, flowers, fruits and buds (Díaz \& Kitzberger 2006), located mainly in the extreme of branches in the upper canopy layer (Martínez Pastur et al. 2008). On the other hand, T. aedon prefer floor stratum probably due to this offer more protection, cover and shelter from predators (mainly Falconiforms and Strigiforms) than other strata. The risk of predation at ground level is low in fuegian Archipelago because native terrestrial predators are almost absent (Rozzi et al. 2010), contrary to Northern Hemisphere (e.g. Canis lupus L., Spaulding et al. 1998; Alopex lagopus L., Liebezeit \& Zack 2008). Recent exotic species introduction in Tierra del Fuego (e.g. Neovison vison) can be a threatening for species with this behaviour (Jaksic et al. 2002).

Contrary, there are birds that varied their strata preferences comparing to those observed in unharvested forests. Some are independent of the variable retention type, as $P$. patagonicus that only occurred in the canopy in unharvested forests, but preferred floor in AR+DR and AR+CC. While T. falcklandii equally preferred canopy and floor in unharvested forest, but moved to the floor in harvested stands. On the other hand, some other species changed their strata preferences according to the variable retention type, as $A$. spinicauda and Z. capensis that used mainly canopy in unharvested forests. However, the first one almost equally chose canopy, floor and debris in AR+DR (ta- 
ble 1), but debris in $\mathrm{AR}+\mathrm{CC}$ (table 2). Meanwhile, the use of debris was maxima for $Z$. capensis in $\mathrm{AR}+\mathrm{DR}$, but they preferred floor in $\mathrm{AR}+\mathrm{CC}$. The preference of floor stratum by $P$. patagonicus, T. falcklandii and Z. capensis could be related to their trophic status (mainly granivorous) and the high abundance of monocots in the understory. Likewise, large size woody debris provides perch sites for singing and other male courtship displays, as well as arthropods that are a significant part of their breeding season diet (DeGraaf \& Yamasaki 2001). Likewise, fine woody debris can offer a nesting substrate and cover for some species, as was described for Z. albicollis by Falls \& Kopachena (2010).

Summarizing, our results suggest that both types of variable retention harvesting $(\mathrm{AR}+\mathrm{DR}$ and $\mathrm{AR}+\mathrm{CC}$ ) provide different habitats to satisfy the requirements of common stenotopic and eurytopic native bird species in N. pumilio forests, contrary to other traditional harvesting systems, as shelterwood cut, that produce homogenization of forest habitats (Gea et al. 2004). Simplification of forest structure and loss of biological legacies, if generalized, will lead to a sharp decline in regional bird species richness and abundance, particularly of some stenotopic, sensitive or specialist species such as large-tree users, but can also affect other use guilds as vertical-profile users (Díaz et al. 2005). On the other hand, generalization of more intense harvesting as clear-cuts, could eliminate some habitats or strata that are important or irreplaceable to ensure the continuity of the life cycle for very specific migratory and resident bird species (Pressey et al. 2007), as E. albiceps and E. ferrugineous. The specific prescription of management guidelines for bird species, such as those developed for several bird species in temperate forests of the world (e.g. Corace 2018, Weiss et al. 2018), requires a detailed knowledge of the autoecology of each species, which is undoubtedly complex in widely distributed and not well-known forests. Active forest management is neces- sary for the conservation of forest-dependent bird species, but affects other landscape and stand-level biodiversity elements (Corace 2018). For example, it would be recommendable the preservation of some forest habitat features as large canopy trees, snags, logs and specific understory covers (Díaz et al. 2005). However, and although it can be easily identified in southern-temperate forests, the practical preservation of these structural features inside harvested areas is difficult. Therefore, alternative harvesting practices that preserve these biological legacies (such as aggregated retentions) could facilitate the design of management plans that enhance bird conservation, while supported goals and objectives are multiple. However, more studies are needed to evaluate the probability of increase the risk of predation, availability of sites for nesting and modifications in the food offer, which could affect the survival of native bird species, compromising their conservation.

\section{Conclusions}

These results support the effectiveness of the variable retention to conserve bird species. The generation of different habitats inside managed forests satisfy both stenotopic and eurytopic species requirements, although some species changed their strata preferences according to the different habitat features provided by variable retention harvesting.

\section{Aknowledgements}

The authors gratefully thank to the Centro Austral de Investigaciones Científicas, Servicios Forestales Consultancy, Los Castores sawmill, Lenga Patagonia S.A. and Dirección de Bosques - Secretaría de Ambiente y Desarrollo Sustentable of Argentina (PIARFON BIRF 4085-AR) for their support during the realization of this work. 


\section{References}

Altamirano T.A., Ibarra J.T., Hernández F., Rojas I., Laker J., Bonacic C., 2012. Hábitos de nidificación de las aves del bosque templado andino de Chile [Nesting habits of the Andean temperate forest birds of Chile]. Fondo de Protección Ambiental, Ministerio del Medio Ambiente. Serie Fauna Australis, Facultad de Agronomía e Ingeniería Forestal, Pontificia Universidad Católica de Chile. 113 p.

Becerra Serial, R., Grigera D., 2005. Dinámica estacional del ensamble de aves de un bosque norpatagónico de lenga (Nothofagus pumilio) y su relación con la disponibilidad de sustratos de alimentación [Seasonal dynamics of the bird assemblage of a north-Patagonic lenga (Nothofagus pumilio) forest and their relation with the availability of feeding substrates]. Hornero 20: 131-139.

Berg Å., Ehnström B., Gustafsson L., Hallingbäck T., Jonsell M., Weslien J., 1994. Threatened plant, animal, and fungus species in Swedish forests: distribution and habitat associations. Conservation Biology 8: 718-731. DOI: 10.1046/j.1523-1739.1994.08030718.x

Brown C.E., Anderson C.B., Ippi S., Sherriffs M.F., Charlin R., McGehee S., Rozzi R., 2007. The autecology of the fío-fío (Elaenia albiceps Lafresnaye \& D'orbigny) in subantarctic forests of the Cape Horn Biosphere Reserve, Chile. Anales Instituto Patagonia 35(2): 29-40.

Catchpole W.R., Wheeler C.J., 1992. Estimating plant biomass: a review of techniques. Austral Journal of Ecology 17: 121-131. DOI: 10.1111/j.1442-9993.1992. tb00790.x

Carrara E., Arroyo-Rodríguez V., Vega-Rivera J.H., Schondube J.E., de Freitas S.M., Fahrig L., 2015. Impact of landscape composition and configuration on forest specialist and generalist bird species in the fragmented Lacandona rainforest, Mexico. Biological Conservation 184: 117-126. DOI: 10.1016/j.biocon.2015.01.014

Clark R., 1986. Aves de Tierra del Fuego y Cabo de Hornos [Birds of Tierra del Fuego and Cabo de Hornos]. Guía de campo. Ed. LOLA, Buenos Aires, Argentina. $277 \mathrm{p}$.

Corace R.G., 2018. Rethinking Forest-Bird Habitat Management Guidelines in the Northern Lake States. Wildlife Society Bulletin 42(2): 347-357. DOI: 10.1002/ wsb. 872

Costello C.A., Yamasaki M., Pekins P.J., Leak W.B., Neefus C.D., 2000. Songbird response to group selection harvests and clearcuts in a New Hampshire northern hardwood forest. Forest Ecology \& Management 127: 41-54. DOI: 10.1016/S0378-1127(99)00131-0

Deferrari G., Camilion C., Martínez Pastur G., Peri P., 2001. Changes in Nothofagus pumilio forest biodiversity during the forest management cycle: 2 . Birds. Biodiversity \& Conservation 10: 2093-2108. DOI: 10.1023/A:1013154824917

DeGraaf R.M., Yamasaki M., 2001. New England Wildlife: Habitat, Natural History and Distribution. Univer- sity Press of New England, Hanover, NH. 496 p.

Devictor V., Julliard R., Jiguet F., 2008. Distribution of specialist and generalist species along spatial gradients of habitat disturbance and fragmentation. Oikos 117(4): 507-514. DOI: 10.1111/j.0030-1299.2008.16215.x

Díaz I.A., Armesto J.J., Reid S., Sieving K.E., Willson M.F., 2005. Linking forest structure and composition: avian diversity in successional forests of Chiloé Island, Chile. Biological Conservation 123(1): 91-101. DOI: 10.1016/j.biocon.2004.10.011

Díaz S., Kitzberger T., 2006. High Nothofagus flower consumption and pollen emptying in the southern South American austral parakeet (Enicognathus ferrugineus). Austral Ecology 31: 759-766. DOI: 10.1111/j.14429993.2006.01637.x

Donázar J., Travaini A., Rodríguez A., Ceballos O., Hiraldo F., 1996. Nesting association of raptors and buffnecked ibis in the Argentinian Patagonia. Colonial Waterbirds 19(1): 111-115. DOI: 10.2307/1521813

Falls J.B., Kopachena J.G., 2010. White-throated Sparrow (Zonotrichia albicollis). In: Poole A., (ed.), The birds of North America online. Ithaca: Cornell Lab of Ornithology.

Franklin J., Berg D., Thornburgh D., Tappeiner J., 1997. Alternative silvicultural approaches to timber harvesting: Variable retention harvest systems. In: Kohm K., Franklin J. (ed.), Creating a Forestry for the 21st Century. Island Press, Washington, DC, pp. 111-140.

French D.D., Picozzi N., 2002. 'Functional Groups' of Bird Species, Biodiversity and Landscapes in Scotland. Journal of Biogeography 29(2): 231-259. DOI: 10.1046/j.1365-2699.2002.00664.x

Gea G., Martínez Pastur G., Cellini J.M., Lencinas M.V., 2004. Forty years of silvicultural management in southern Nothofagus pumilio (Poepp. et Endl.) Krasser primary forests. Forest Ecology and Management 201: 335-347. DOI: 10.1016/j.foreco.2004.07.015

Gossner M.M., Fonseca C.R., Pašalić E., Türke M., Lange M.M., Weisser W.W., 2014. Limitations to the use of arthropods as temperate forests indicators. Biodiversity \& Conservation 23: 945-962. DOI: 10.1007/s10531014-0644-3

Gustafsson L., Baker S.C., Bauhus J., Beese W.J., Brodie A., Kouki J., Lindenmayer D.B., Lõhmus A., Martínez Pastur G.J., Messier C., Neyland M., Palik B., Sverdrup-Thygeson A., Volney W.J.A., Wayne A., Franklin J.F., 2012. Retention Forestry to Maintain Multifunctional Forests: A World Perspectiva. BioScience 62(7): 633-645. DOI: 10.1525/bio.2012.62.7.6

Hill M.O., 1979. DECORANA. A Fortran program for detrended correspondence analysis and reciprocal averaging. Publ. of Section of Ecology and Systematics, Cornell Univ. Ithaca, New York. 52 p.

Humphrey P., Bridge D., Reynolds P., Peterson R., 1970. Birds of Isla Grande (Tierra del Fuego). Ed Smithsonian Institution, Washington. $411 \mathrm{p}$.

Jaksic F.M., Iriarte J.A., Jiménez J.E., Martínez D.R., 2002. Invaders without frontiers: cross-border inva- 
sions of exotic mammals. Biological Invasions 4: 157173. DOI: $10.1023 / \mathrm{A}: 1020576709964$

King D.I., DeGraaf R.M., 2000. Bird species diversity and nesting success in mature, clearcut and shelterwood forest in northern New Hampshire, USA. Forest Ecology \& Management 129: 227-235. DOI: 10.1016/S03781127(99)00167-X

Liebezeit J.R., Zack S., 2008. Point counts underestimate the importance of Arctic foxes as avian nest predators: evidence from remote video cameras in Arctic Alaskan oil fields. Arctic 61: 153-161.

Lemmon P., 1957. A new instrument for measuring forest overstory density. Journal of Foresttry 55(9): 667668.

Lencinas M.V., Martínez Pastur G., Medina M., Busso C., 2005. Richness and density of birds in timber Nothofagus pumilio forests and their unproductive associated environments. Biodiversity \& Conservation 14: 22992320. DOI: $10.1007 / \mathrm{s} 10531-004-1665-0$

Lencinas M.V., Martínez Pastur G., Rivero P., Busso C., 2008a. Conservation value of timber quality versus associated non-timber quality stands for understory diversity in Nothofagus forests. Biodiversity \& Conservation 17 (11): 2579-2597. DOI: 10.1007/s10531-0089323-6

Lencinas M.V., Martínez Pastur G., Solán R., Gallo E., Cellini J.M., 2008b. Forest management with variable retention impact over bryophyte communities of Nothofagus pumilio understory. Forstarchiv 79: 7782.

Lencinas M.V., Martínez Pastur G., Anderson C.B., Busso C., 2008c. The value of timber quality forests for insect conservation on Tierra del Fuego Island compared to associated non-timber quality stands. Journal of Insect Conservation 12: 461-475. DOI: 10.1007/s10841-0079079-4

Lencinas M.V., Martínez Pastur G., Gallo E., Cellini J.M., 2009. Alternative silvicultural practices with variable retention improve bird conservation in managed South Patagonian forests. Forest Ecology \& Management 258: 472-480. DOI: 10.1016/j.foreco.2009.01.012

Lencinas M.V., Martínez Pastur G.J., Gallo E., Cellini J.M., 2011. Alternative silvicultural practices with variable retention to improve understory plant diversity conservation in southern Patagonian forests. Forest Ecology \& Management 262: 1236-1250. DOI: 10.1016/j.foreco.2011.06.021

Lencinas M.V., Martínez Pastur G.J., Gallo E., Cellini J.M., 2014. Decreasing negative impacts of harvesting over insect diversity using variable retention silviculture in southern Patagonian forests. Journal of Insect Conservation 18: 479-495. DOI: 10.1007/s10841-0149661-5

Lencinas M.V., Sola F., Martínez Pastur G., 2017. Variable retention effects on vascular plants and beetles along a regional gradient in Nothofagus pumilio forests. Forest Ecology \& Management 406: 251-265. DOI: 10.1016/j. foreco.2017.10.014
Martínez Pastur G.J., Peri P., Vukasovic R., Vaccaro S., Piriz Carrillo V., 1997. Site index equation for Nothofagus pumilio Patagonian forest. Phyton 6(1/2): 55-60.

Martínez Pastur G., Lencinas M.V., Peri P., Moretto A., Cellini J.M., Mormeneo I., Vukasovic R., 2007. Harvesting adaptation to biodiversity conservation in sawmill industry: Technology innovation and monitoring program. Journal of Technology, Management \& Innovtion 2(3): 58-70.

Martínez Pastur G., Lencinas M.V., Peri P.L., Cellini J.M., 2008. Flowering and seeding patterns in unmanaged and managed Nothofagus pumilio south Patagonian forests. Forstarchiv 79: 60-65.

Martínez Pastur G., Lencinas M.V., Cellini J.M., Peri P.L., Soler R., 2009. Timber management with variable retention in Nothofagus pumilio forests of Southern Patagonia. Forest Ecology \& Management 258: 436-443. DOI: 10.1016/j.foreco.2009.01.048

Martínez Pastur G., Cellini J.M., Lencinas M.V., Barrera M.D., Peri P.L., 2010. Environmental variables influencing regeneration of Nothofagus pumilio in system with combined aggregated and dispersed retention. Forest Ecology \& Management 261: 178-186. DOI: 10.1016/j.foreco.2010.10.002

Martínez Pastur G., Lencinas M.V., Gallo E., De Cruz M., Borla M., Soler R., Anderson C., 2015. Habitat-specific vegetation and seasonal drivers of bird community structure and function in southern Patagonian forests. Community Ecology 16(1): 55-65. DOI: 10.1556/168.2015.16.1.7

Martínez Pastur G., Peri P.L., Soler R., Schindler S., Lencinas M.V., 2016. Biodiversity potential of Nothofagus forests in Tierra del Fuego (Argentina): Tool proposal for regional conservation planning. Biodiversity \& Conservation 25(10): 1843-1862. DOI: $10.1007 /$ s10531-016-1162-2

McCune B., Mefford M.J., 1999. Multivariate analysis of ecological data, Version 4.0, MjM software. Gleneden Beach, Oregon, USA. 337 p.

MEA (Millennium Ecosystem Assessment), 2005. Ecosystems and human wellbeing: current state and trends. Washington (DC): Island Press. 948 p.

Mueller-Dombois D., Ellenberg H., 1974. Aims and Methods of Vegetation Ecology. John Wiley and Sons, New York, USA. 547 p.

Narosky T., Yzurieta D., 1987. Guía para la identificación de aves de Argentina y Uruguay [Guide for the identification of birds of Argentina and Uruguay.]. Asociación Ornitológica del Plata, Buenos Aires, Argentina, 346 p.

O’Donnell F.J., Dilks P.J., 1988. A method for quantifying habitat use by forest birds. Wellington, Science and Research Directorate, Department of Conservation. Sience \& Research Series No4. 20 p.

Partasasmita R., Atsuary Z.I.A., Husodo T., 2017. The use of forest canopy by various bird species in tropical forest montana zone, the Nature Reserve of Mount Tilu, West Java, Indonesia. Biodiversitas 18(2): 453-457. 
DOI: $10.13057 /$ biodiv/d180202

Pearson D.L., 1971. Vertical stratification of birds in a tropical dry forest. The Condor 73(1): 46-55. DOI: $10.2307 / 1366123$

Peri P.L., Lencinas M.V., Bousson J., Lasagno R., Soler R., Bahamonde H., Martínez Pastur G., 2016. Biodiversity and ecological long-term plots in Southern Patagonia to support sustainable land management: The case of PEBANPA network. Journal of Nature Conservation 34: 51-64. DOI: 10.1016/j.jnc.2016.09.003

Perry D.A., Amaranthus M.P., 1997. Disturbance, recovery, and stability. In: Kohm K., Franklin J. (eds.), Creating a Forestry for the 21st Century. Island Press, Washington, DC, pp. 31-56.

Pressey R.L., Cabeza M., Watts M.E., Cowling R.M., Wilson K.A., 2007. Conservation planning in a changing world. Trends in Ecology \& Evolution 22(11): 583-592. DOI: $10.1016 /$ j.tree.2007.10.001

Rozzi R., Martínez D., Willson M.F., Sabag C., 1997. Avifauna of South American temperate forests. In: Armesto J., Villagrán C., Arroyo M.T.K. (eds.), Ecología de los bosques nativos de Chile. Editorial Universitaria, Universidad de Chile (Chile), pp. 135-152.

Rozzi R., Anderson C.B., Pizarro J.C., Massardo F., Medina Y., Mansilla A., Kennedy J.H., Ojeda J., Contador T., Morales V., Moses K., Poole A., Armesto J.J., Kalin M.T., 2010. Field environmental philosophy and biocultural conservation at the Omora Ethnobotanical Park: methodological approaches to broaden the ways of integrating the social component ("S") in LongTerm Socio-Ecological Research (LTSER) Sites. Revista Chilena de Historia Natural 83: 27-68.

Schlatter R., 1995. Ornithology. Technical Report: Subproyecto 94-14. Estudios de línea base: Proyecto Río Condor. Punta Arenas (Chile). 51 p.

Sekercioglu C.H., 2006. Ecological significance of bird populations. In: J. del Hoyo A.E., Christie D.A. (eds.), Handbook of the Birds of the World, vol. 11. Lynx Press and BirdLife International, Barcelona and Cambridge, pp. $15-51$.

Shields W.M., 1977. The effect of time of day on avian census results. The Auk 94: 380-383.

Smith Ramírez C., Armesto J., 1998. Nectarivoría y polinización por aves en Embothrium coccineum (Proteaceae) en el bosque templado del sur de Chile [Nec- tarivory and pollination by birds in Embothrium coccineum (Proteaceae) in the temperate forest of southern Chile]. Revista Chilena de Historia Natural 71(1): 5163.

Soler R., Schindler S., Lencinas M.V., Peri P.L., Martínez Pastur G., 2015. Retention forestry in southern Patagonia: Multiple environmental impacts and their temporal trends. International Forestry Review 17(2): 231-243. DOI: $10.1505 / 146554815815500589$

Spaulding R.L., Krausman P.R., Ballard W.B., 1998. Summer diet of Gray Wolves, Canis lupus, in northwestern Alaska. Canadian Field Naturalist 112: 262-266.

Traveset A., Willson M., Sabag C., 1998. Effect of nectar-robbing birds on fruit set of Fuchsia magellanica in Tierra del Fuego: a disrupted mutualism. Functional Ecology 12(3): 459-464. DOI: 10.1046/j.13652435.1998.00212.x

Venegas C., 1986. Aves de Patagonia y Tierra del Fuego Chileno-argentina [Birds of Chilean-Argentine Patagonia and Tierra del Fuego]. Ediciones de la Universidad de Magallanes. Punta Arenas (Chile), 79 p.

Venegas C., 2000. Avifauna de un bosque de lenga (Nothofagus pumilio) intervenido y de uno no intervenido en Magallanes continental, Chile [Birds of primary and amanged forests of continental Magellan, Chile]. Anales del Instituto de la Patagonia 28: 101-106.

Vuilleumier F., 1985. Forest birds of Patagonia: ecological geography, speciation, endemism, and faunal history. Ornithology Monographs 36: 255-304. DOI: $10.2307 / 40168287$

Weiss S.A., Corace R.G., Toman E.L., Herms D.A., Goebel P.C., 2018. Wildlife implications across snag treatment types in jack pine stands in eastern Upper Michigan. Forest Ecology and Management 409: 407-416. DOI: $10.1016 /$ j.foreco.2017.10.013

Whelan C.J., Wenny D.G., Marquis R.J., 2008. Ecosystem services provided by birds. Annals of the New York Academy of Sciences 1134(1): 25-60. DOI: 10.1196/ annals. 1439.003

Zolotarjova V., Kraut A., Lõmus A., 2016. Slash harvesting does not undermine beetle diversity on small clearcuts containing sufficient legacies. Journal of Insect Conservation 20: 285-294. DOI: 10.1007/s10841-0169865-y 